Stenhouse. His most noteworthy early discovery perhaps is that involved in the use of iodine as a catalyst in chlorinating. $\mathrm{He}$ was an intimate friend of Kekulé when the latter was in London.

A man of great personal charm of manner, of sympathetic nature and very versatile, he inspired confidence not only by the breadth and accuracy of his knowledge but also by his calm and clear judgment. His worth was soon recognised, so that he was consulted constantly by the firm of De la Rue and Co. long before he was induced to give up science and enter upon an industrial career in its service; ultimately he became a partner in the firm and remained in it until 1902 The Stamp department was his chief charge; in this he found full opportunity for the exercise of his scientific ability and great technical skill as well as of his artistic gifts. He was elected a fellow of the Royal Society in 1866 . He joined the Chemical Society in 1859; he was its foreign secretary from 1869 to 1885 and president in $1885^{-87}$. He was a Ph.D. of Göttingen, an LL.D. of St. Andrews and a D.Sc. of Manchester. He became naturalised thirty-seven years ago, on his marriage to an English lady. He had two daughters, one of whom and his wife survive him.

When the Lawes Agricultural Trust was constituted by his old friend Sir John Lawes twentysix years ago, he was appointed a representative of the Royal Society on the Committee and became the treasurer; he held the office until the present year, when he retired, in spite of the urgent requests of his colleagues that he. would not sever the connection; but he thought that German residents in this country, whether naturalised or not, were so seriously affected by the outbreak of the war that it was not desirable that a person in his position should be a member of or take: part in the affairs of any public concern or enterprise. He consistently remained aloof from everything.

Although his time was fully occupied by his business avocations while in the firm of De la Rue and Co., he never lost his interest in his science; since his retirement he worked regularly in the Davy-Faraday laboratory of the Royal Institution. The work he did, which has been published by the Chemical Society, is remarkable a: proof of his exceptional skill as a manipulator and of special value to science. Only recently he completed the investigation of the peculiar bloom which appears on the leaf and flower-stalk of a number of species of primula; he made the striking discovery that this consists of flavone, the parent substance of the great group of yellow colouring matters present in plants, a substance only prepared in the laboratory previously.

Dr. Müller was also a noted horticulturist and botanist; he was long an active member of the scientific committee of the Royal Horticultural Society. Beginning thirty years ago with a sandy waste at Camberley, Surrey, he developed one of the most remarkable and beautiful gardens in the country. His knowledge of plants was quite exceptional, as it had long been his habit to grow them in order that he might know them; his garden, therefore, was always of special interest.
A man of large and noble mind, he was torn with distress by the outbreak of the war, which he looked upon as a downfall of civilisation; he deplored his having lived to see it and there is little doubt that his end was greatly hastened by recent events.

\section{DR. M. W. CROFTON, F.R.S.}

DR. M. W. CROFTON, whose death was recently announced in NATURE, was born in Dublin in the year 1826 , the son of Rev. William Crofton, of Sligo, a clergyman of the Established Church. Together with his brother Henry, who was two years his junior, he entered Trinity College, Dublin, in the year I 843 under the tutorship of Dr. Graves, who afterwards became professor of mathematics in the college, and later Bishop of Limerick. Diligent students both brothers must have been, for at the moderatorship examination in 1847 Morgan, who had captured on the way all the undergraduate prizes open to him, came out first of his class in mathematics, while Henry headed the list in classics, a double event rare, if not unique, in the history of the College.

When the Queen's University of Ireland was established, Dr. Crofton was appointed professor of natural philosophy at Queen's College, Galway, a position which he resigned in 1853 after three years' occupation. He was afterwards professor of mathematics and mechanics in the Royal Military Academy, Woolwich, from 1870 until r884, and on his resignation was appointed to a fellowship of the Royal University of Ireland, retaining that position until i 895. Dr. Crofton published a treatise on the "Elements of Applied Mechanics" (London, r88I), and contributed several papers on geometry and mechanics to various journals, but his chief interest was in the mathematical theory of probability. There is a paper of his in the Phil. Trans. of the year I 868 "on the theory of local probability applied to random straight lines," and another in the Phil. Trans. of 1869 "on the proof of the laws of errors of observations." He wrote also the chapter on mean value and probability in Williamson's "Integral Calculus," and the article, "Probability," in the ninth edition of the Encyclopædia Britannica.

Dr. Crofton was elected a Fellow of the Royal Society in 1868 .

S. B. Kelleher.

\section{NOTES.}

We notice with much regret the announcement of the death, on May $3 \mathrm{r}$, in his eighty-first year, of Sir A. H. Church, K.C.V.O., F.R.S., formerly professor of chemistry in the Royal Academy of Arts.

MEN of science view with especial satisfaction the appointment of Admiral Sir Henry Jackson, K.C.B., F.R.S., as First Sea Lord of the Admiralty. So far as we are aware no precedent exists for the nomination of a fellow of the Royal Society as First Sea Lord of the Admiralty. Born on January 2I, $18_{55}$, Sir Henry entered the Navy at thirteen, became Lieu-

NO. 2379, VOL. 95] 